\title{
Calcareous Nannofossils Biostratigraphy of Aaliji Formation in Well (K- 116), Northern Iraq
}

\author{
Raghda Saad Al-Hyaly Omar Ahmed Al-Badrani \\ Department of Geology \\ College of Science \\ University of Mosul
}

(Received 13/11/2018，Accepted 27/1/2019)

\begin{abstract}
Thirteen samples of Aaliji Formation from the well (K-116), Kirkuk area, Northern Iraq, are studied on the basis of the stratigraphic ranges of the recorded calcareous nannofossils for sixty species, the studied section reveals five biozones arranged from oldest to youngest as follows:

1. Fasciculithus tympaniformis Interval Biozone (CP4)

2. Heliolithus kleinpellii Interval Biozone (CP5)

3. Discoaster mohleri Interval Biozone (CP6)

4. Discoaster nobilis Interval Biozone (CP7)

5. Discoaster multiraditus Interval Biozone (CP8)

These biozones are correlated with other calcareous nannofossils biozones from both local and regional sections leading to conclude the age of Middle Paleocene to Early Eocene.
\end{abstract}

Key words: Calcareous nannofossils, Biostratigraphy, Paleocene, Iraq.

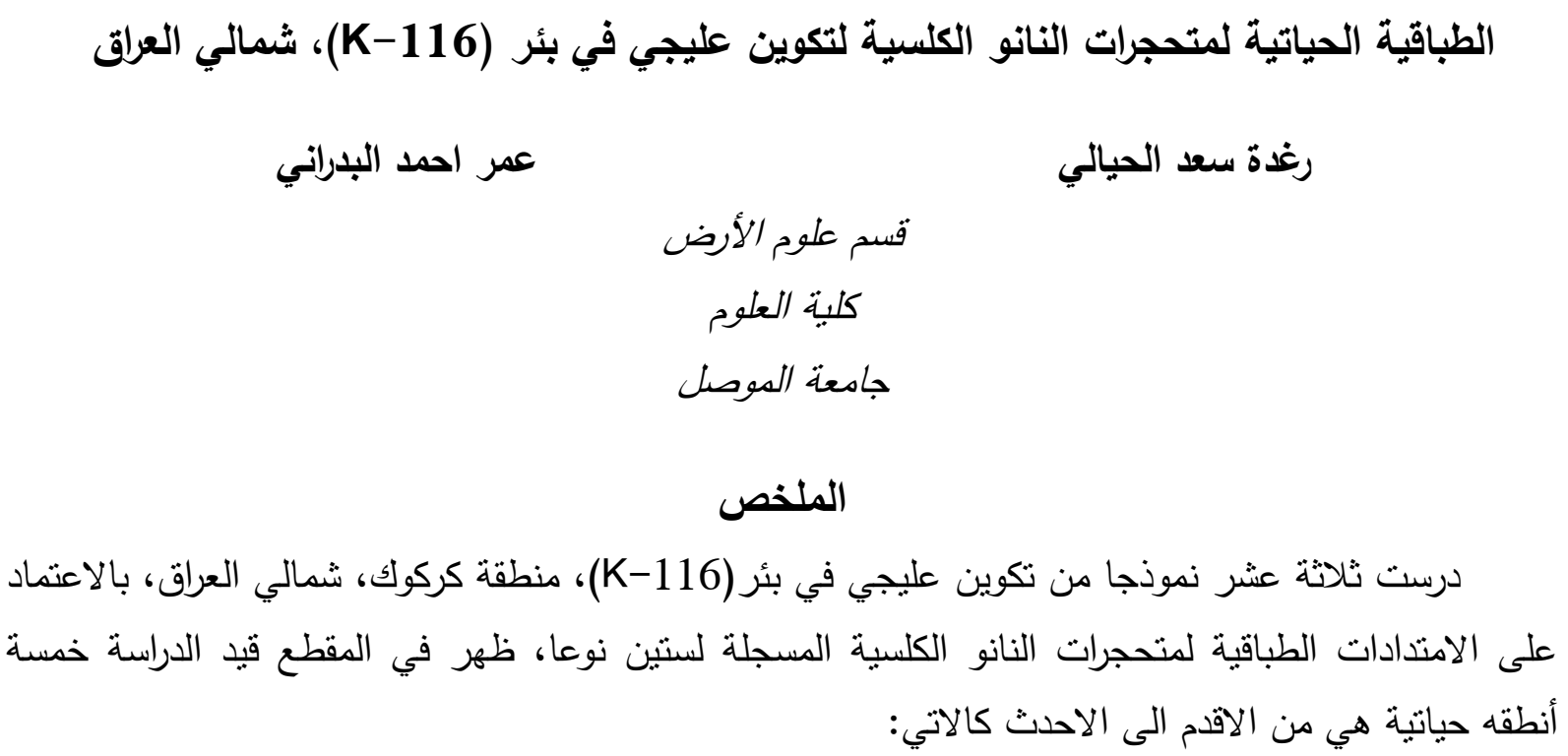

1. Fasciculithus tympaniformis Interval Biozone (CP4)

2. Heliolithus kleinpellii Interval Biozone (CP5)

3. Discoaster mohleri Interval Biozone (CP6) 
4. Discoaster nobilis Interval Biozone (CP7)

5. Discoaster multiraditus Interval Biozone (CP8)

تمت مضاهاة الانطقة الحالية مع الانطقة العالمية واستتجج عمر التكوين بالباليوسين الاوسط الى الايوسين

الكلمات الدالة: تكوين عليجي، منطقة كركوك، الطباقية الحياتية، باليوسين، أنطقه حياتية.

\section{INTRODUCTION}

Aaliji Formation was first described in northwest Syria (Meidannki, lat. $36^{\circ} 29^{\prime}$ $25^{\prime \prime} \mathrm{N}$, long. $36^{\circ} 53^{\prime} 32^{\prime \prime}$ E) A supplementary type locality has been chosen in Iraq is

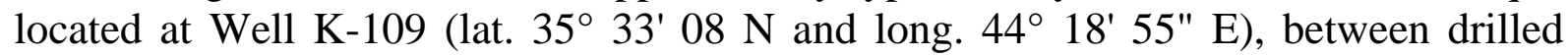
depths 2487 feet and 3035 feet, so the thickness is 548 feet (167 meters) (Bellen et. al., 1959).

The studied section that lies in Kirkuk area at (K-116) (lat. 35 $47^{\prime \prime} 28^{\prime} \mathrm{N}$ and long. $43^{\circ} 59^{\prime \prime} 06^{\prime}$ E) consists of marlstone and marly limestone between drilled depths $1441 \mathrm{~m}$. and $1375 \mathrm{~m}$., so the thickness is about $64 \mathrm{~m}$ (Fig. 1).

Twenty-Three samples of marly limestone and marl are selected for the studying the calcareous nannofossils using the thin sections (under transmitted-light microscope). The calcareous nannofossils are extracted by using the method $(\mathrm{H})$ (Armstrong and Brasier, 2005).

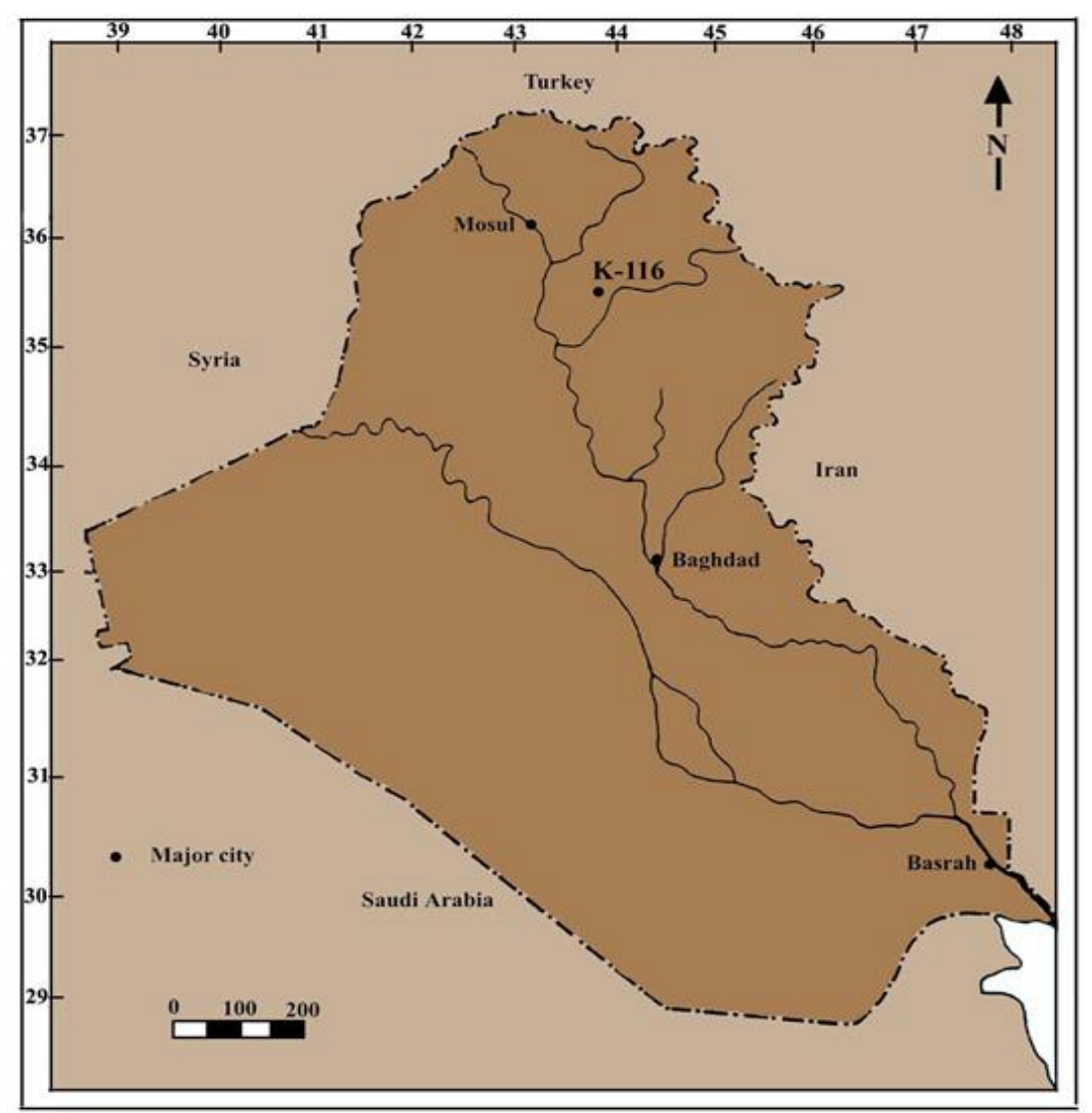

Fig. 1: Location map for the studied section at K-116 Materials and Methods 


\section{NANNOBIOSTRATIGRAPHY}

Depending on the stratigraphic distribution of the recorded species, five Biozones are identified (Fig.2):

\section{1 - Fasciculithus tympaniformis Interval Biozone (CP4) (Part)}

Definition: Interval biozone of Fasciculithus tympaniformis Hay and Mohler, 1967.

Boundaries: The biozone determinate by FO of Fasciculithus tympaniformis Hay and Mohler, 1967 to FO of Heliolithus kleinpellii Sullivan, 1964.

Thickness: (4750-4700) ft.

Correlation and Discussion: This biozone correlated with Fasciculithus tympaniformis biozone (CP4) by Okada and Bukry (1980) which aged Middle Paleocene (Selandian), and correlated with Fasciculithus tympaniformis biozone (NP5) by Martini (1971) which aged Middle Paleocene (Selandian) too. Therefore, depending on stratigraphic correlation above this biozone aged Middle Paleocene (Selandian) (Gradstein et al., 2012).

\section{2- Heliolithus kleinpellii Interval Biozone (CP5) (CP11)}

Definition: Interval biozone of Heliolithus kleinpellii Sullivan, 1964.

Boundaries: The biozone determinate by FO of Heliolithus kleinpellii Sullivan, 1964 to FO Discoaster mohleri (Bukry and Perciavel, 1971).

Thickness: (4700-4670) ft.

Correlation and Discussion: This biozone correlated with Heliolithus kleinpellii biozone (CP5) by Okada and Bukry (1980) which aged Middle to late Paleocene (Selandianto Thanetian), and correlated with Heliolithus klenpellii biozone (NP6) by Martini (1971) which aged Middle to Late Paleocene (Selandian to Thanetian) too. Therefore, depending on stratigraphic correlation above this biozone aged Middle to Late Paleocene (Selandian to Thanetian) (Gradstein et al., 2012).

\section{3 - Discoaster mohleri Interval Biozone (CP6)}

Definition: Interval biozone of Discoaster mohleri Bukry and Perciavel, 1971.

Boundaries: The biozone determinate by FO of Discoaster mohleri Bukry and Perciavel, 1971 to FO of Discoaster nobilis Martini, 1961

Thickness: (4670-4640) ft.

Correlation and Discussion: This biozone correlated with Discoaster mohleri biozone (CP6) by Okada and Bukry (1980) which aged Late Paleocene (Thenetian), and correlated with Discoaster mohleri biozone (NP7) by Martini (1971) which aged Late Paleocene (Thanetian) too. Therefore, depending on stratigraphic correlation above this biozone aged Late Paleocene (Thanetian) (Gradstein et al., 2012). 


\section{4 - Discoaster nobilis Interval Biozone (CP7)}

Definition: Interval biozone of Discoaster nobilis Martini, 1961.

Boundaries: The biozone determinate by FO of Discoaster nobilis Martini, 1961 to FO Discoaster multiradiatus Bramlette and Riedel, 1954.

Thickness: (4640-4590) ft.

Correlation and Discussion: This biozone correlated with Discoaster nobilis biozone (CP7) by Okada and Bukry (1980) which aged Late Paleocene (Thenetian), and correlated with Discoaster nobilis biozone (NP8) by Martini (1971) which aged Late Paleocene (Thanetian) too. Therefore, depending on stratigraphic correlation above, this biozone aged Late Paleocene (Thanetian) (Gradstein et al., 2012).

\section{5- Discoaster multiradiatus Interval Biozone (CP8) (part)}

Definition: Interval biozone of Discoaster multiradiatus Bramlette and Riedel, 1954.

Boundaries: The biozone determinate by FO of Discoaster multiradiatus Bramlette and Riedel, 1954 to FO of Discoaster diastypus Bramlette and Sullivan, 1961.

Thickness: (4590-4540) ft.

Correlation and Discussion: This biozone correlated with Discoaster multiradiatus biozone (CP8) by Okada and Bukry (1980) which aged Late Paleocene to Early Eocene (Thanetian to Ypresian), and correlated with Discoaster multiradiatus biozone (NP9) by Martini (1971) which aged Late Paleocene to Early Eocene(Thanetian to Ypresian) too. Therefore, depending on stratigraphic correlation above this biozone aged Late Paleocene to Early Eocene (Thanetian to Ypresian) (Gradstein et al., 2012).

\section{CONCLUSIONS}

Aaliji Formation in (K-116) well consist of five boizones for calcareous nannofossils, these are from older to younger (Figs.2, 3):

1. Fasciculithus tympaniformis Interval Biozone (CP4)

2. Heliolithus kleinpellii Interval Biozone (CP5)

3. Discoaster mohleri Interval Biozone (CP6)

4. Discoaster nobilis Interval Biozone (CP7)

5. Discoaster multiradiatus Interval Biozone (CP8)

This biozones aged Middle Paleocene to Early Eocene for studied section (Fig.4). 


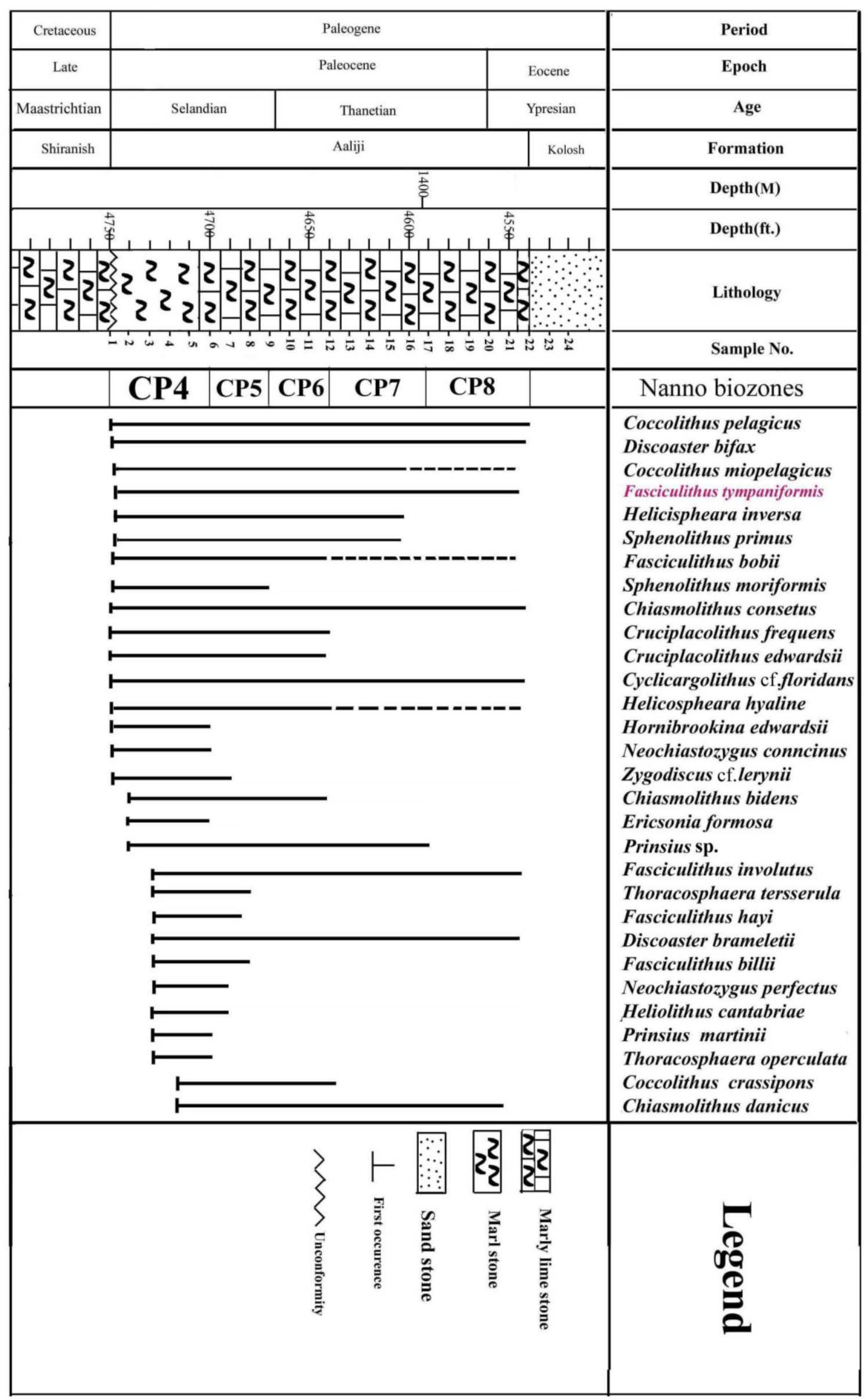

Fig. 2a: Biostratigraphic chart of studied section. 


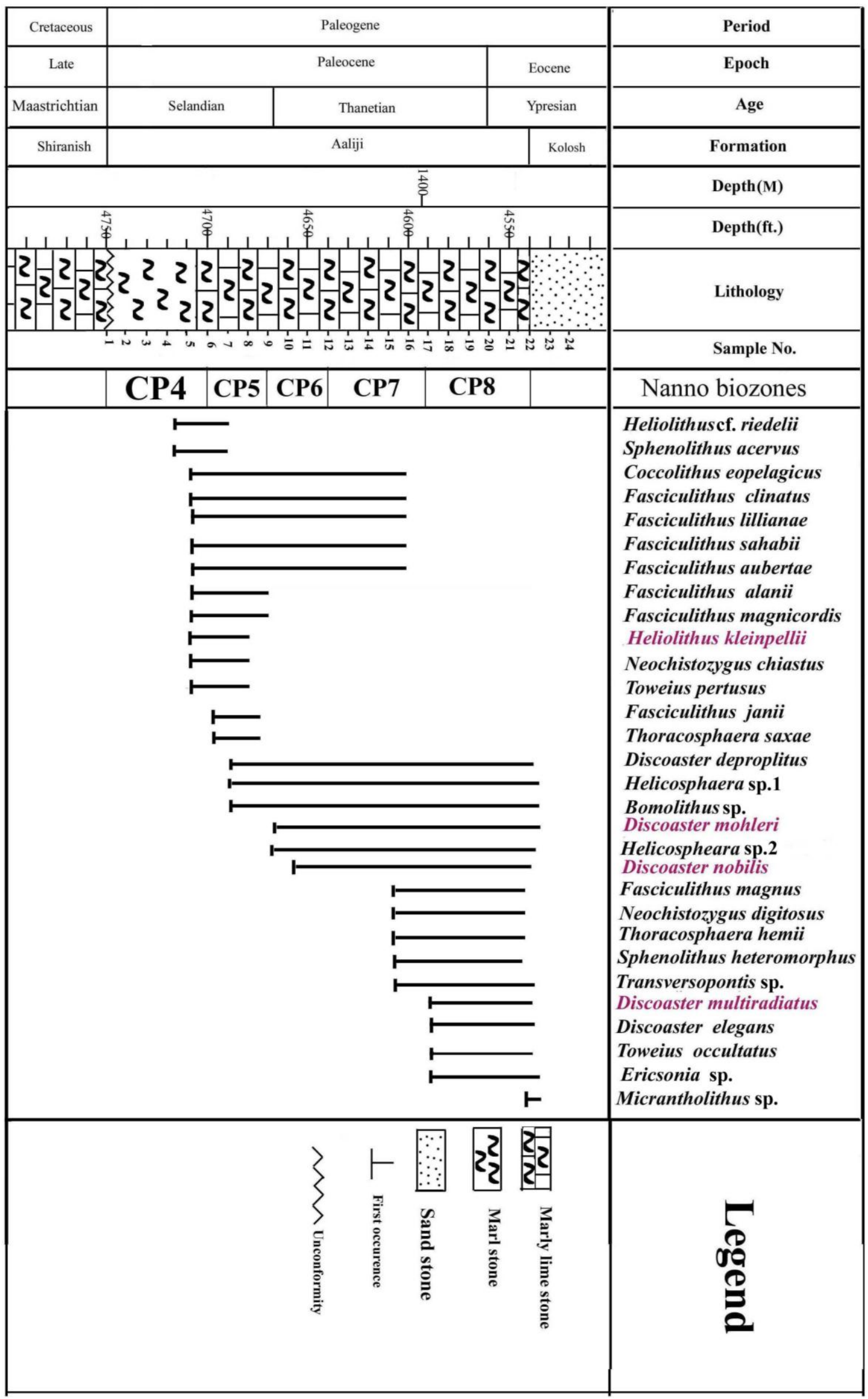

Fig. 2b: Biostratigraphic chart of studied section. 


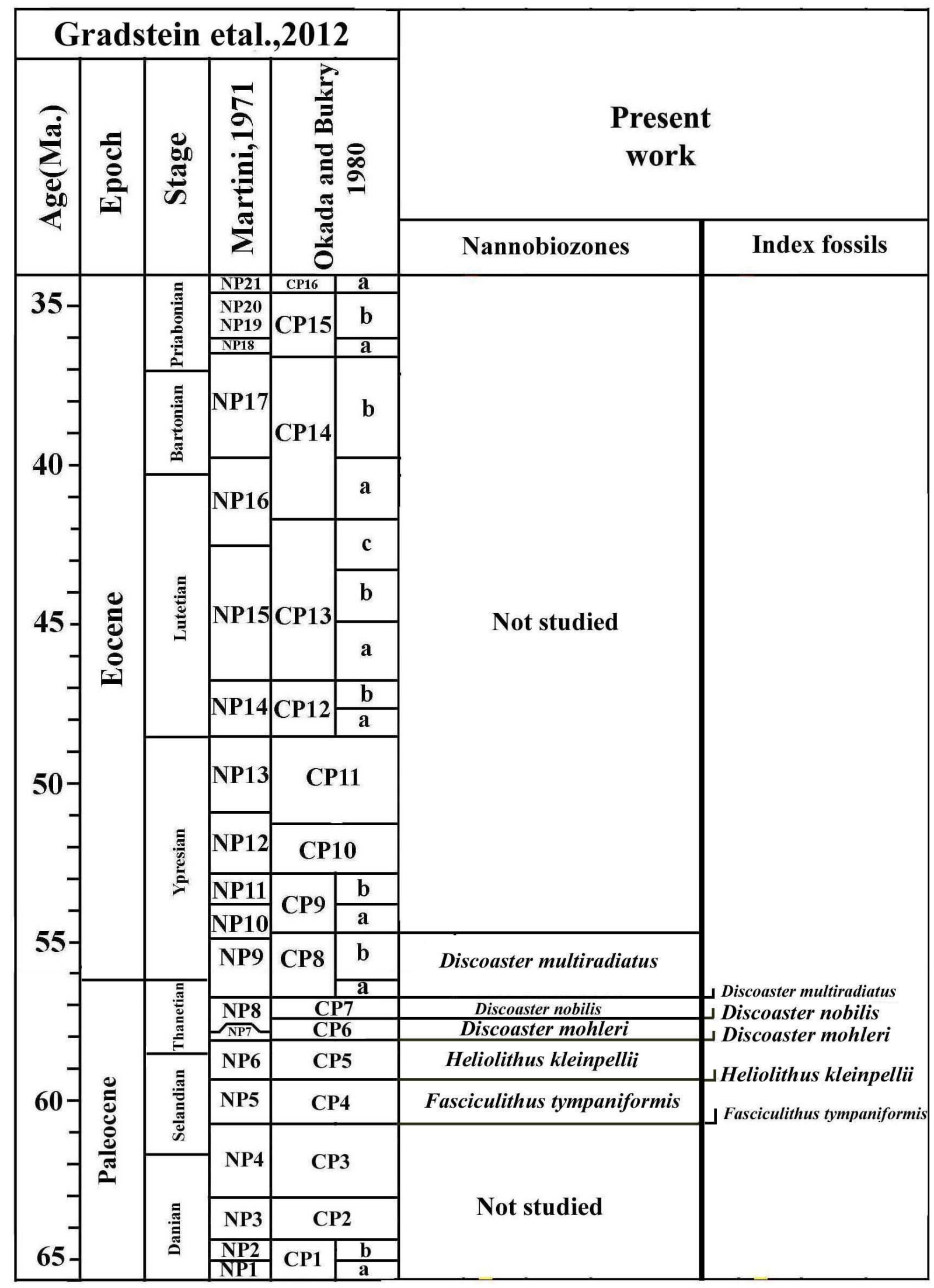

Fig. 3: Index calcareous nannofossils species for studied section. 


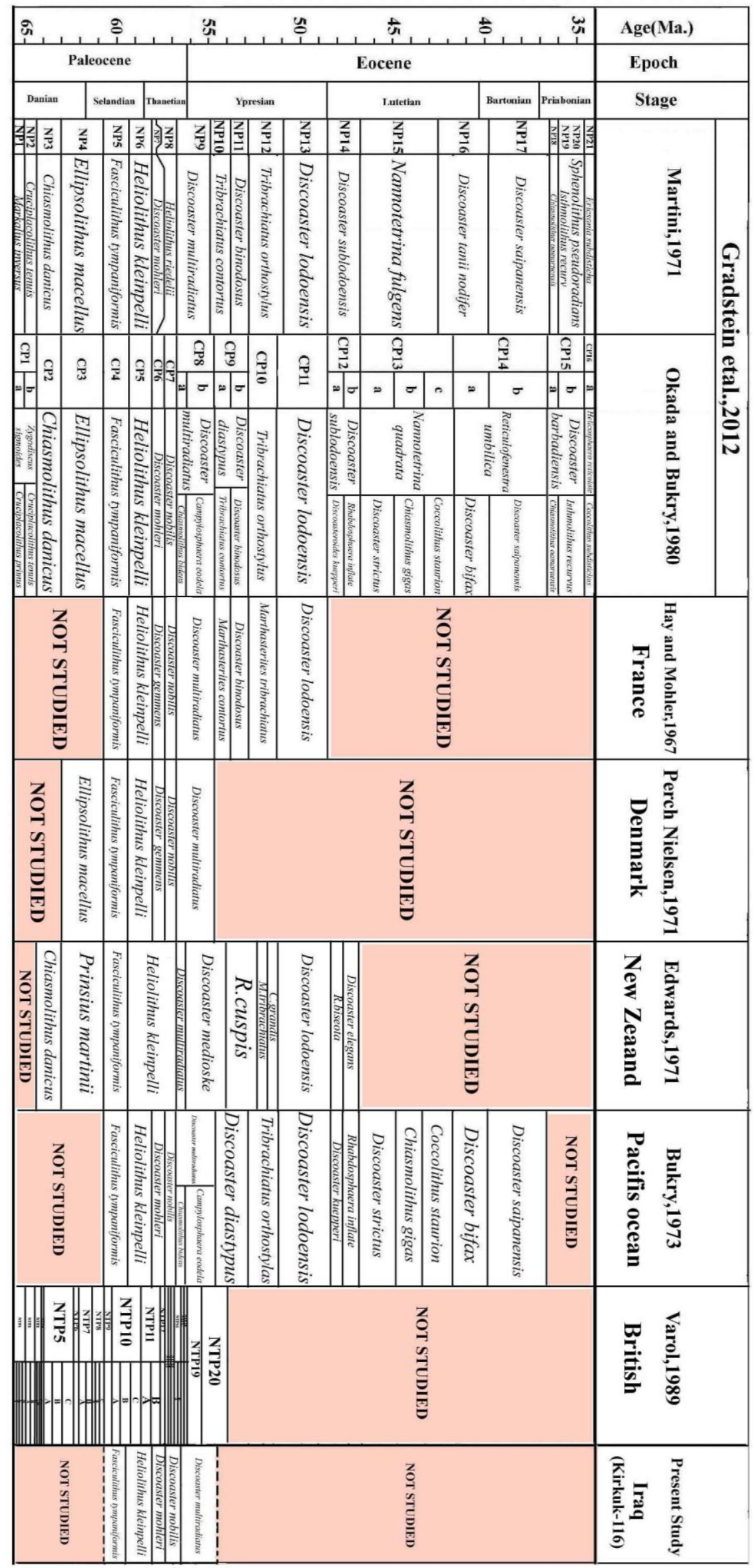

Fig. 4: Comparisons between calcareous nannofossils biozones for studied section. 


\section{REFERENCES}

Armstrong, H. and Brasier, M., 2005. Microfossils. Blackwell Publishing, 296 p.

Bellen, R. C. Van, Dunnington, H. V., Wetzel, R. and Morton, D. M., 1959. Lexique Stratigraphique international, Vol. III. Asie, Fascicule 10 a, Iraq, 333 p.

Bramlette, M.N. and Riedel, W.R., 1954. Stratigraphic value of Discoasters and some other microfossils related to recent coccolithophores. J. Paleontology, Vol.28, No.4, pp.385-403.

Bramlette, M.N. and Sullivan, F.R., 1961. Coccolithophorids and related nannoplankton of the early Tertiary in California. Micropaleontology, Vol.7, No. 2, pp. $129-188$, pls. 1-14.

Bukry, D. and Percival, S.F., 1971. New Tertiary calcareous nannofossils. Tulane Stud. Geol. Paleont., No.8, pp.123-146, pls.1-7.

Bukry, D., 1973. Coccolith stratigraphy, eastern equatorial Pacific, Leg 16 Deep Sea Drilling Project. In: van Andel, T.H., 1-Health, G.R., et al., Initial report of the Deep Sea Drilling Project. Volume XVI. Washington, D.C., US. Gov. Printing Office, pp. 653-71 1, Pls.1 -5, text-figs. 1-4, table 1-6.

Edwards, A. R., 1971. A calcareous nannoplankton zonation of New Zealand Paleogene. In: Farinacci (ed.), Proceedings ח Planktonic Conference Roma, 1970, 1, pp.381- 419.

Gradstein, F.M., Ogg, J.G., Schmitz, M.D. and Ogg, G.M., 2012. The Geologic Time Scale 2012, Elsevier, 1000p.

Hay, W.W., Mohler, H.P. and Wade, M.E., 1966. Calcareous nannofossils from Nalchik (northwest Caucasus). Eclog. Geol. Helve, No.59, pp. 379-99.

Hay, W.W., and Mohler, H.P., 1967. Calcareous, nannoplankton from Early Tertiary Rocks at Pont Labau, France, and Paleocene - Early Eocene Correlations. J. Paleontology, Vol. 41, No. 6, pp. 1505 -1541, pls 196 -206, text - figs, 1-5.

Martini, E., 1961. Nannoplankton aus dem Tertiär und der Obersten Kreide von SWFrankreich. Ibid 42, pp. 1-40, Pl. 5.

Martini, E., 1971. Standard Tertiary and Quaternary calcareous nannoplankton zonation. In Farinacci, A., (Ed.), Proceedings II Planktonic Conference, Roma, 1970, No.2, pp. 739-785, Pl. 4, fig. 6.

Okada, H. and Bukry, D., 1980. Supplementary modification and introduction of code numbers to low-latitude coccolith biostratigraphy zonation (Bukry, 1973, 1975). Marine Micro- Paleontology., Vol.5, No.3, pp .321- 326.

Edwards, A. R., 1971. Acalcareous nannoplankton zonation of newzeland Paleogene. In: A. Farinacci (ed), Proceedings ח Planktonic Conference Roma, 1970, No.1, pp.381- 419.

Sullivan, F. R., 1964. Lower Tertiary nannoplankton from the California Coast Ranges, I. Paleocene. Univ. Calif. Publ. Geol. Sci., Vol.44, No.3, pp.163 -227.

Varol, O., 1989. Eocene calcareous nannofossils from Sile (northwest Turkey). Revista Espaola de Micropaleontology, Vol. 21, pp. 273-320. 


\section{PLATE EXPLANATIONS}

1, 2 Thoracosphaera tersserula Fütter, 1978, bar $=5$ micron, (1) Polarized Light Photo (2) Gypsum Light Photo.

3, 4 Heliolithus klenpellii Sullivan, 1964, bar $=5$ micron, (1) Polarized Light Photo (2) Gypsum Light Photo.

5, 6 Fasciculithus tympaniformis Hay and Mohler, 1967 in Hay, Mohler and Roth, 1967, bar $=5$ micron, (1) Polarized Light Photo.

7, 8 Sphenolithus acervus Bown, 2005, bar $=5$ micron, (1) Polarized Light Photo (2) Gypsum Light Photo.

9 Discoater mohleri Bukry and Percival, 1971, bar $=5$ micron, (1) Normal Light Photo.

10 Discoater multiradiatus Bramlette and Riedel, 1954, bar $=5$ micron, (1) Normal Light Photo.

11 Discoaster nobilis Martini, 1961, bar $=5$ micron, (1) Normal Light Photo

12 Discoaster deproplitus Martini, 1961, bar = 5 micron, (1) Normal Light Photo. 
PLATE

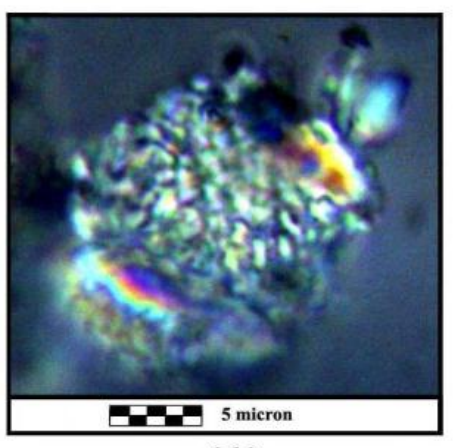

(1)

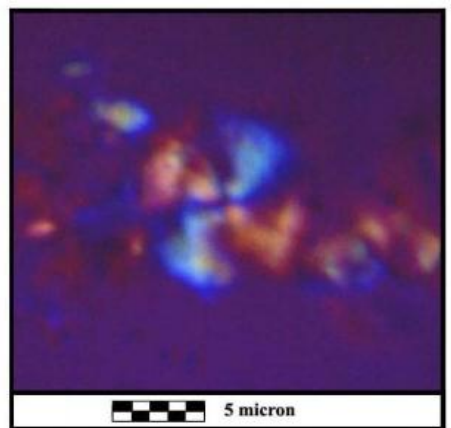

(4)

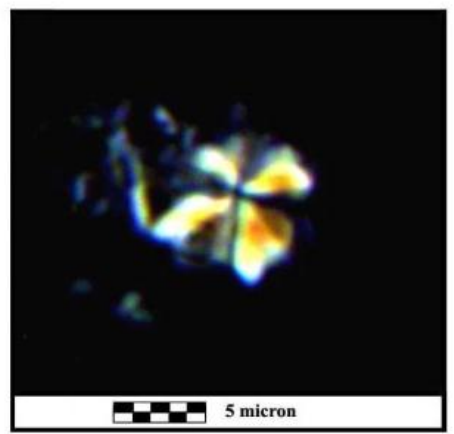

(7)

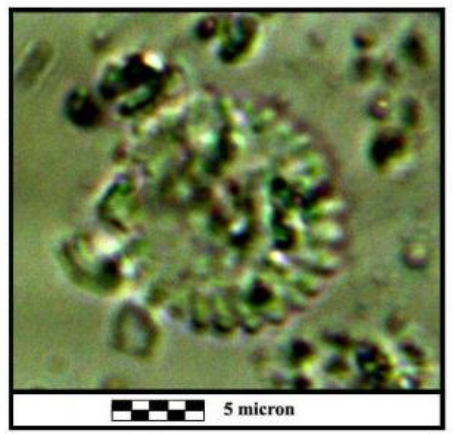

(10)

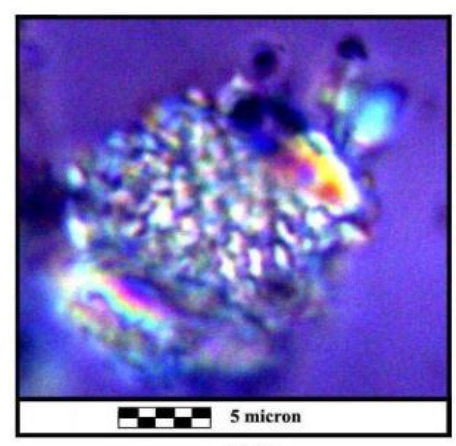

(2)

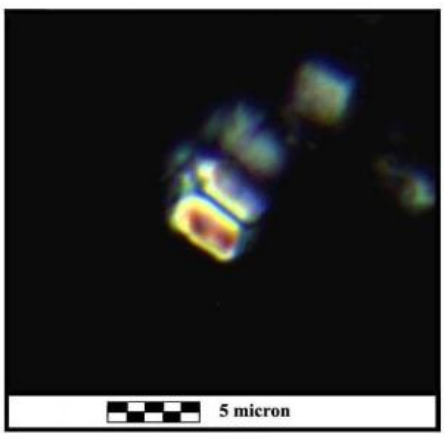

(5)

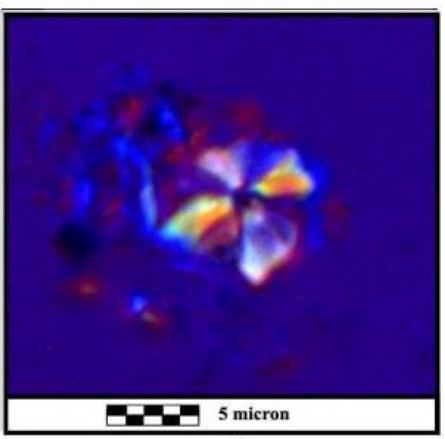

(8)

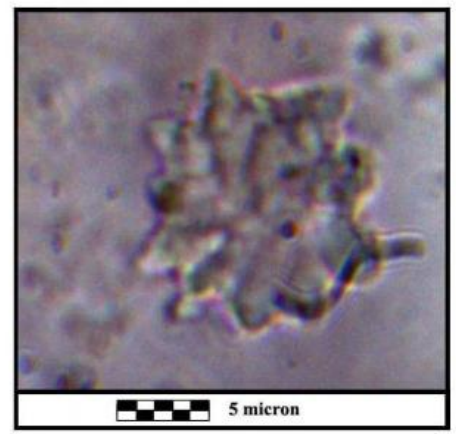

(11)

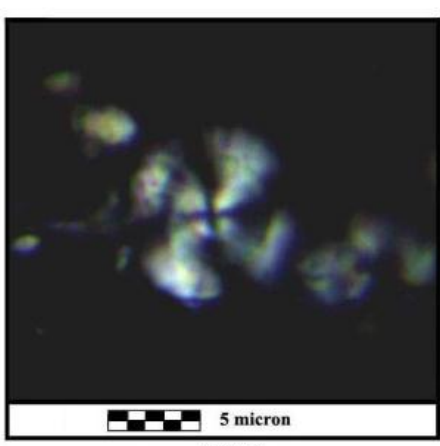

(3)

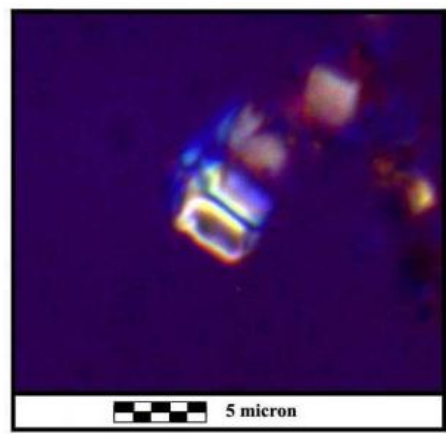

(6)

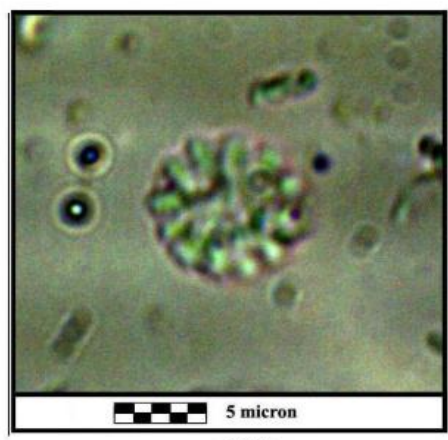

(9)

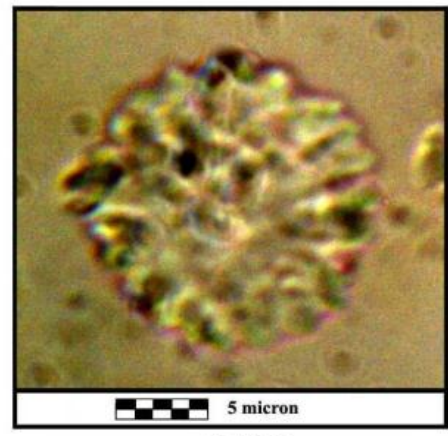

(12) 